\title{
Effect of Age on the Initiation of Biologic Agent Therapy in Patients With Inflammatory Bowel Disease: Korean Common Data Model Cohort Study
}

Youn I Choi ${ }^{1}$, MD; Yoon Jae Kim ${ }^{1}, \mathrm{MD}$, PhD; Jun-Won Chung ${ }^{1}$, MD, PhD; Kyoung Oh Kim ${ }^{1}$, MD, PhD; Hakki $\mathrm{Kim}^{2}$, BSc; Rae Woong Park ${ }^{3}$, MD, PhD; Dong Kyun Park ${ }^{1}$, MD, PhD

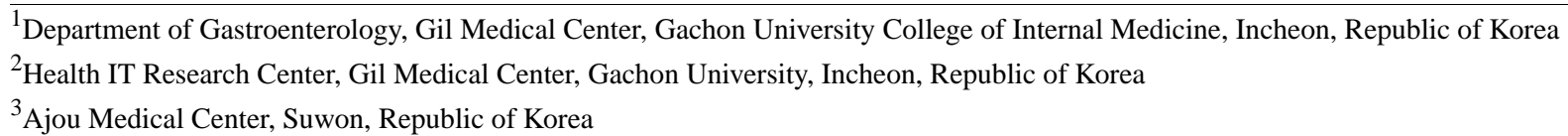

\section{Corresponding Author:}

Yoon Jae Kim, MD, PhD

Department of Gastroenterology

Gil Medical Center

Gachon University College of Internal Medicine

21, Namdong-daero 774 beon-gil

Namdong-gu, Incheon 405-760

Incheon, 21565

Republic of Korea

Phone: 821025670067

Email: Yoonmed@gachon.ac.kr

\section{Abstract}

Background: The Observational Health Data Sciences and Informatics (OHDSI) network is an international collaboration established to apply open-source data analytics to a large network of health databases, including the Korean common data model (K-CDM) network.

Objective: The aim of this study is to analyze the effect that age at diagnosis has on the prognosis of inflammatory bowel disease (IBD) in Korea using a CDM network database.

Methods: We retrospectively analyzed the K-CDM network database from 2005 to 2015 . We transformed the electronic medical record into the CDM version 5.0 used in OHDSI. A worsened IBD prognosis was defined as the initiation of therapy with biologic agents, including infliximab and adalimumab. To evaluate the effect that age at diagnosis had on the prognosis of IBD, we divided the patients into an early-onset (EO) IBD group (age at diagnosis <40 years) and a late-onset (LO) IBD group (age at diagnosis $\geq 40$ years) with the cutoff value of age at diagnosis as 40 years, which was calculated using the Youden index method. We then used the logrank test and Cox proportional hazards model to analyze the effect that age at diagnosis (EO group vs LO group) had on the prognosis in patients with IBD.

Results: A total of 3480 patients were enrolled. There was 2017 patients with ulcerative colitis (UC) and 1463 with Crohn's disease (CD). The median follow up period was 109.5 weeks. The EO UC group was statistically significant and showed less event-free survival (ie, experiences of biologic agents) than the LO UC group $(P<.001)$. In CD, the EO CD group showed less event-free survival (ie, experiences of biologic agents) than the LO CD group. In the Cox proportional hazard analysis, the odds ratio (OR) of the EO UC group on experiences of biologic agents compared with the LO UC group was 2.3 (95\% CI 1.3-3.8, $P=.002)$. The OR of the EO CD group on experiences of biologic agents compared with the LO CD group was 5.4 (95\% CI 1.9-14.9, $P=.001)$.

Conclusions: The EO IBD group showed a worse prognosis than the LO IBD group in Korean patients with IBD. In addition, this study successfully verified the CDM model in gastrointestinal research.

(JMIR Med Inform 2020;8(4):e15124) doi: $\underline{10.2196 / 15124}$

\section{KEYWORDS}

ulcerative colitis; Crohn's disease; early-onset; late-onset; common data model 


\section{Introduction}

The incidence of inflammatory bowel disease (IBD) is increasing in newly industrialized and westernized countries [1-5]. Although the incidence of IBD in western countries is stabilizing, its prevalence remains less than $0.3 \%$. A major issue among IBD patients is the deterioration in disease-related events $[1,6,7]$.

Effective management of IBD requires the ability to predict and prevent acute exacerbation events [1], and several studies have focused on prognostic factors for IBD [5,8-11]. Dulai et al [12] in the United States demonstrated that a history of biologic agent use, bowel surgery, fistulizing events, baseline albumin levels, and C-reactive protein levels are associated with the prognosis of Crohn's disease (CD). Khan et al [13] reported that early corticosteroid use is an independent risk factor for the prognosis of ulcerative colitis (UC). Baars et al [14] showed that late-onset (LO) IBD is associated with the development of colorectal cancer, and Israeli et al [15] reported that early-onset (EO) IBD is associated with worse outcomes, more complex diseases, and the need for surgery.

However, data regarding the factors associated with a poor prognosis of IBD are inconclusive, particularly for the second exacerbation event after diagnosis of IBD. Moreover, there is little data available related to the prediction of IBD prognosis, especially in Asian patients.

To identify factors at the time of diagnosis that are associated with the prognosis of IBD, we used the verified Korean common data model (K-CDM) network [16,17]. The K-CDM, which follows the policy of the Observational Health Data Sciences and Informatics (OHDSI) network [18,19], is an electronic medical record (EMR) standard. The CDM has evolved since its launch in the latter half of 2016. The network facilitates the performance of efficient and transparent multicenter studies $[16,17]$. However, the K-CDM has not been applied to gastrointestinal research.

This study was performed to evaluate the effect of age at diagnosis on the prognosis of IBD by using the CDM format of OHDSI resources, and to assess the effectiveness of a new methodology that codes algorithms via $\mathrm{K}-\mathrm{CDM}$ of OHDSI network.

\section{Methods}

\section{Institutional Ethic Review Board Approval of the Study Design}

The Institutional Review Board of Gil Medical Center (GMC) reviewed the study protocol (certification number:
GAIRB2018-127). Since the data were analyzed anonymously, consent was not obtained.

\section{Financial Support}

This research was supported by the Basic Science Research Program through the National Research Foundation of Korea, funded by the Ministry of Education (2017R1D1A1B03034546), and supported by a grant from the Korea Health Technology R\&D Project through the Korea Health Industry Development Institute (KHIDI), funded by the Ministry of Health \& Welfare, Republic of Korea (grant number: HI14C3201).

\section{The OHDSI Network and Korean Common Data Model Resources}

The OHDSI network is an international collaboration that aims to develop data-sharing systems $[18,19]$ by applying open-source data analytics to a large number of health databases. Each member of the OHDSI network transfers their EMR databases to the CDM.

The K-CDM is based on the OHDSI database framework (CDM version 5.0). The OHDSI network launched in 2015, and the K-CDM launched in the latter half of 2016. The uploading of the EMRs from Korean hospitals into the K-CDM continued until the second half of 2019. More detailed information regarding the extract, transform, load system of longitudinal health care databases into the CDM has been described in previous studies [20-22].

\section{Study Design and Data Sources}

We conducted a multicenter, retrospective, cross-sectional study of the clinical history, medical treatment history, and laboratory parameters of patients with IBD according to their age at diagnosis of IBD using the K-CDM network resources.

To assess the effectiveness of our methodology, we used the CDM coding algorithms. The tertiary centers in the K-CDM use the same EMRs; therefore, we queried their CDM databases to extract the data of interest [20-22].

\section{Identification of Patients With Inflammatory Bowel Disease}

The K-CDM database was used to identify all patients diagnosed for the first time with UC or CD (according to the International Classification of Disease codes) from January 1, 2006, to December 31, 2016.

We included patients who were followed up with for at least 2 months and excluded those misdiagnosed with other chronic IBDs including intestinal tuberculosis $[23,24]$. Tuberculosis is endemic in Korea, and thus intestinal tuberculosis is not rare [25]. To prevent misdiagnosis of intestinal tuberculosis as IBD or vice versa, a 2-month course of anti-tuberculosis agents and a follow-up colonoscopy are recommended [23] (Figure 1). 
Figure 1. Study flow. OHDSI: Observational Health Data Sciences and Informatics Network; GMC: Gil Medical Center; AMC: Ajou Medical Center; IBD: inflammatory bowel disease.

\section{OHDSI network in Korea (GMC, AMC) \\ Exclusion criteria \\ -patients younger than 16 years \\ -patients who followed up less than 2 \\ months}

IBD patients were enrolled $(n=3480)$

\section{Definitions of Early-Onset and Late-Onset Inflammatory Bowel Disease}

EO and LO IBD were defined as patients being diagnosed younger than 40 years and 40 years of age or older, respectively. To avoid the misclassification of LO IBD caused by loss of medical records, we designed a washout period of 1 year. Since IBD disease is a chronic and life-long disorder, using a 1 year washout period prevents misconduct in this study.

\section{Outcome Measures}

A worsened prognosis of IBD was defined as initiation of biologic-agent therapy. Unlike other nations, in Korea, physicians are not allowed to prescribe biologic agents to patients with IBD who are diagnosed as IBD for the first time, even with severe disease activity. Biologic agents are only prescribed for patients with IBD who are unresponsive to, dependent on, or contraindicated for steroids or immunosuppressants [26-32]. Therefore, biologic-agent therapy is typically delayed until the second exacerbation event or until the patient is unresponsive to or dependent on steroids or immunosuppressants for at least 3 months after the diagnosis of IBD. In Korea, use of biologic agents is indicative of a poor prognosis [28,32-34].

\section{Variables}

We assessed the following variables: date of the initial diagnosis of IBD, age at initial diagnosis of IBD, current age, sex, laboratory parameters, and history of IBD treatment (including systemic steroids and immunosuppressants). Treatment history was extracted from the CDM databases of the participating institutions. We regarded use of systemic steroids or immunosuppressants at diagnosis as indicators of disease activity at diagnosis. The Korean IBD treatment guidelines state that systemic steroids or immunosuppressive agents should be used only in patients with moderate or severe diseases $[33,35]$.

\section{Statistical Analysis}

Since there have been debates on whether age at diagnosis is independent of risk factors for worsening prognosis in IBD patients, we investigated the effect of age at diagnosis on the prognosis of IBD patients using the OHDSI K-CDM network database.

We calculated the cutoff value of age at diagnosis to predict a worsened prognosis (use of biologic agents) in IBD patients from the GMC registry using the Youden index method. Using this process, we determined the cutoff values of age at diagnosis ( $<40$ years of age and $\geq 40$ years of age), which showed the best performance of prognosis prediction for patients with IBD.

We then externally validated whether the cutoff values of age at diagnosis ( $<40$ years vs $\geq 40$ years) showed a reasonable prediction of a worsened prognosis in patients with IBD using the K-CDM network database.

The cumulative incidence (Kaplan-Meier method) of using biologic agents throughout the follow-up period according to age group was evaluated by the logrank test. The hazard ratio for the initiation of biologic agents was compared between patients with EO vs LO UC and patients with EO vs LO CD. All statistical tests were two-sided, and a value of $P<.05$ was considered indicative of statistical significance. The data was analyzed using SPSS Statistics version 22 (IBM, Armonk, NY) and MedCalc version 12.2.1 (MedCalc Software, Ostend, Belgium).

\section{Results}

\section{Clinical Characteristics and Outcomes}

From 2005 to 2015,3480 patients were diagnosed with incident IBD, of whom 2017 (57.96\%) had UC and 1463 (42.04\%) had CD (Table 1). The median follow-up duration from the date of initial diagnosis of IBD was 109.5 weeks. The mean ages at diagnosis of EO UC $(1015,50.32 \%)$ and LO UC (1002, 49.68\%) were 25.7 and 55.4 years, respectively. The mean ages at diagnosis of EO CD $(1059,72.39 \%)$ and LO CD (404, 27.61\%) were 21.9 and 55.0 years, respectively. 
Table 1. Baseline characteristics of all patients with inflammatory bowel disease $(\mathrm{N}=3480)$.

\begin{tabular}{|c|c|c|}
\hline Characteristics & Ulcerative colitis $(\mathrm{N}=2017)$ & Crohn's disease $(\mathrm{N}=1463)$ \\
\hline Follow-up period (weeks), mean (range) & $132.73(26.43-318.92)$ & $87.43(14.01-248.42)$ \\
\hline Male, n (\%) & $1153(57.16)$ & $939(64.18)$ \\
\hline \multicolumn{3}{|l|}{ Age of participants } \\
\hline Current age (years), mean (SD) & $49.91(16.92)$ & $48.94(18.43)$ \\
\hline Age at diagnosis (years), mean (SD) & $41.40(17.61)$ & $29.72(17.10)$ \\
\hline Age at diagnosis $<40, \mathrm{n}(\%)$ & $1015(50.32)$ & 1059 (72.39) \\
\hline Age at diagnosis $\geq 40, \mathrm{n}(\%)$ & $1002(49.68)$ & $404(27.61)$ \\
\hline \multicolumn{3}{|l|}{ Phenotype of IBD ${ }^{a}$} \\
\hline Systemic steroid use at diagnosis, $\mathrm{n}(\%)$ & $261(12.94)$ & $183(12.51)$ \\
\hline \multicolumn{3}{|l|}{ IBD related outcome (biologic agent) } \\
\hline Age at IBD related event, mean (SD) & $39.51(16.39)$ & $31.40(14.81)$ \\
\hline Experience of biologic agent, $\mathrm{n}(\%)$ & $104(5.16)$ & $177(12.10)$ \\
\hline \multicolumn{3}{|l|}{ Laboratory data (at diagnosis) } \\
\hline Hematocrit $(\%)$, mean (SD) & $38.89(5.59)$ & $38.38(5.63)$ \\
\hline Serum total bilirubin $(\mathrm{mg} / \mathrm{dL})$, mean $(\mathrm{SD})$ & $0.71(0.52)$ & $0.59(0.38)$ \\
\hline Serum albumin $(\mathrm{g} / \mathrm{dL})$, mean $(\mathrm{SD})$ & $4.12(0.51)$ & $3.99(0.61)$ \\
\hline Serum creatinine $(\mathrm{mg} / \mathrm{dL})$, mean $(\mathrm{SD})$ & $1.12(4.82)$ & $0.81(0.72)$ \\
\hline Serum C-reactive protein $(\mathrm{g} / \mathrm{dL})$, mean $(\mathrm{SD})$ & $1.81(3.69)$ & $2.39(3.98)$ \\
\hline
\end{tabular}

${ }^{\mathrm{a}}$ IBD: inflammatory bowel disease.

\section{Association Between Age at Diagnosis and Ulcerative Colitis or Crohn's Disease Phenotype}

The rate of previous use of systemic steroid therapy at the time of diagnosis was not significantly different in the EO UC group than in the LO UC group $(131 / 1015,12.91 \%$ vs $130 / 1002,12.97 \%, P=.91$ ) (Table 2); however, the rate was significantly higher in the EO CD group than in the LO CD group $(144 / 1059,13.60 \%$ vs $39 / 404,9.7 \%, P=.04)$ (Table 3 ).
Previous biologic-agent therapy, serum albumin, and blood urea nitrogen differed significantly between the EO UC and LO UC groups (Table 2).

Systemic steroid use at diagnosis, previous biologic-agent therapy, male sex, age, hematocrit levels, serum total bilirubin, and serum creatinine levels differed significantly between the EO CD and LO CD groups (Table 3). 
Table 2. Univariate analysis biologic agent experience between early onset and late onset groups in ulcerative colitis (N=2017).

\begin{tabular}{|c|c|c|c|}
\hline Characteristics & $\begin{array}{l}\text { Early onset } U^{a} \text { (age at diagnosis }<40 \\
\text { years) }(N=1015)\end{array}$ & $\begin{array}{l}\text { Late onset } \mathrm{UC} \text { (age at diagnosis } \\
\geq 40 \text { years) }(\mathrm{N}=1002)\end{array}$ & $P$ value \\
\hline Follow-up period (weeks), mean (SD) & $156.90(156.70)$ & $190.70(175.80)$ & .005 \\
\hline Male, $\mathrm{n}(\%)$ & $590(58.13)$ & $563(56.19)$ & .40 \\
\hline Current age (years), mean (SD) & $33.60(10.00)$ & $63.90(11.10)$ & $<.001$ \\
\hline \multicolumn{4}{|l|}{ Phenotype of IBD ${ }^{b}$} \\
\hline Systemic steroid use at diagnosis, $\mathrm{n}(\%)$ & $131(12.91)$ & $130(12.97)$ & .91 \\
\hline \multicolumn{4}{|l|}{ IBD related outcome (biologic agent) } \\
\hline Age at experience of biologic agent (years), mean (SD) & $26.13(8.81)$ & $54.93(9.42)$ & $<.001$ \\
\hline Experienced biologic agent, n (\%) & $64(6.31)$ & $40(3.99)$ & $<.001$ \\
\hline \multicolumn{4}{|l|}{ Laboratory data (at diagnosis) } \\
\hline Hematocrit $(\%)$, mean (SD) & $39.21(5.99)$ & $38.71(5.22)$ & .32 \\
\hline Serum albumin $(\mathrm{g} / \mathrm{dL})$, mean $(\mathrm{SD})$ & $4.19(0.59)$ & $4.12(0.51)$ & $<.001$ \\
\hline Serum blood urea nitrogen $(\mathrm{mg} / \mathrm{dL})$, mean $(\mathrm{SD})$ & $11.09(3.68)$ & $14.39(5.48)$ & $<.001$ \\
\hline Serum creatinine $(\mathrm{mg} / \mathrm{dL})$, mean $(\mathrm{SD})$ & $0.83(0.42)$ & $1.29(6.49)$ & .23 \\
\hline C-reactive protein $(\mathrm{g} / \mathrm{dL})$, mean $(\mathrm{SD})$ & $2.01(3.71)$ & $1.69(3.59)$ & .32 \\
\hline
\end{tabular}

${ }^{\mathrm{a}} \mathrm{UC}$ : ulcerative colitis.

${ }^{\mathrm{b}} \mathrm{IBD}$ : inflammatory bowel disease.

Table 3. Univariate Analysis of biologic agent experience between early onset and late onset group in Crohn's disease (N=1463).

\begin{tabular}{|c|c|c|c|}
\hline Characteristics & $\begin{array}{l}\text { Early onset } C^{2}{ }^{a} \text { (age at diagnosis }<40 \\
\text { years) }(N=1059)\end{array}$ & $\begin{array}{l}\text { Late onset } \mathrm{CD} \text { (age at diagnosis } \\
\geq 40 \text { years) }(\mathrm{N}=404)\end{array}$ & $P$ value \\
\hline Follow-up period (weeks), mean (SD) & $106.29(125.91)$ & $163.48(155.93)$ & $<.001$ \\
\hline Male, $\mathrm{n}(\%)$ & $728(68.74)$ & $211(52.23)$ & $<.001$ \\
\hline Current age (years), mean (SD) & $28.81(9.69)$ & $63.32(12.11)$ & $<.001$ \\
\hline \multicolumn{4}{|l|}{ Phenotype of IBD ${ }^{b}$} \\
\hline Systemic steroid use at diagnosis, $\mathrm{n}(\%)$ & $144(13.60)$ & $39(9.65)$ & .04 \\
\hline \multicolumn{4}{|l|}{ IBD related outcome (biologic agent) } \\
\hline Age at experience of biologic agent (years), mean (SD) & $23.48(8.53)$ & $54.09(10.32)$ & $<.001$ \\
\hline Experience of biologic agent, $\mathrm{n}(\%)$ & $144(13.60)$ & $33(8.17)$ & $<.001$ \\
\hline \multicolumn{4}{|l|}{ Laboratory data (at diagnosis) } \\
\hline Hematocrit (\%), mean (SD) & $38.91(5.18)$ & $36.72(6.34)$ & .001 \\
\hline Serum total bilirubin (mg/dL), mean (SD) & $0.62(0.39)$ & $0.74(0.42)$ & .04 \\
\hline Serum albumin $(\mathrm{g} / \mathrm{dL})$, mean $(\mathrm{SD})$ & $4.11(0.57)$ & $4.02(0.63)$ & .31 \\
\hline Serum creatinine $(\mathrm{mg} / \mathrm{dL})$, mean $(\mathrm{SD})$ & $0.73(0.42)$ & $1.14(1.27)$ & .007 \\
\hline C-reactive protein $(\mathrm{g} / \mathrm{dL})$, mean $(\mathrm{SD})$ & $3.69(4.01)$ & $2.2(3.99)$ & .59 \\
\hline
\end{tabular}

${ }^{\mathrm{a}} \mathrm{CD}$ : Crohn's disease.

${ }^{\mathrm{b}} \mathrm{IBD}$ : inflammatory bowel disease.

Association Between Age at Diagnosis and Initiation of Biologic-Agent Therapy

The EO UC group had a significantly lower event-free survival rate than that of the LO UC group $(P<.001)$. The rate of biologic-agent therapy initiation was significantly higher in the EO UC group than in the LO UC group $(P<.001)$ (Figure 2$)$. The rate of biologic-agent initiation therapy was also significantly higher in the EO CD group than in the LO CD group $(P<.001)$ in the total K-CDM population (Figure 3$)$. 
Figure 2. Kaplan-Meier analysis for experience of biologic agents in patients with ulcerative colitis.

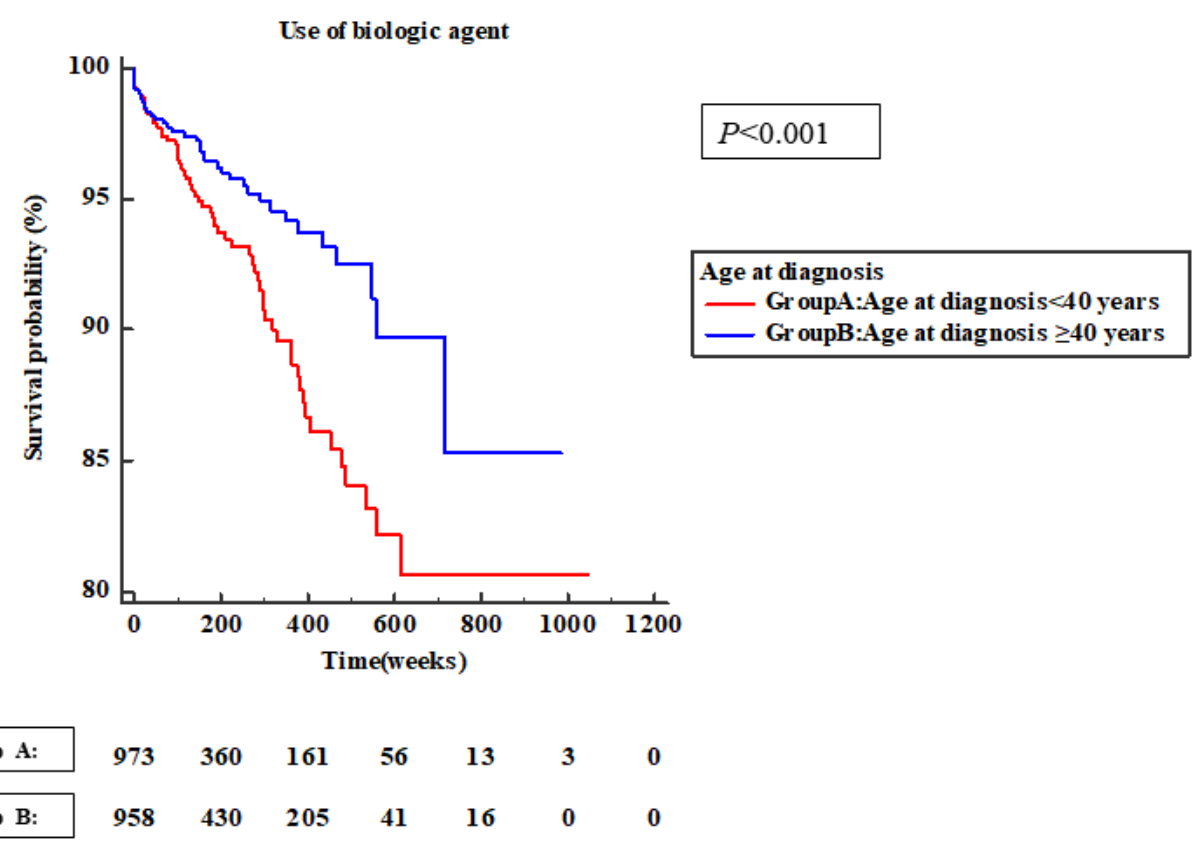

Figure 3. Kaplan-Meier analysis for experience of biologic agents in patients with Crohn's disease.

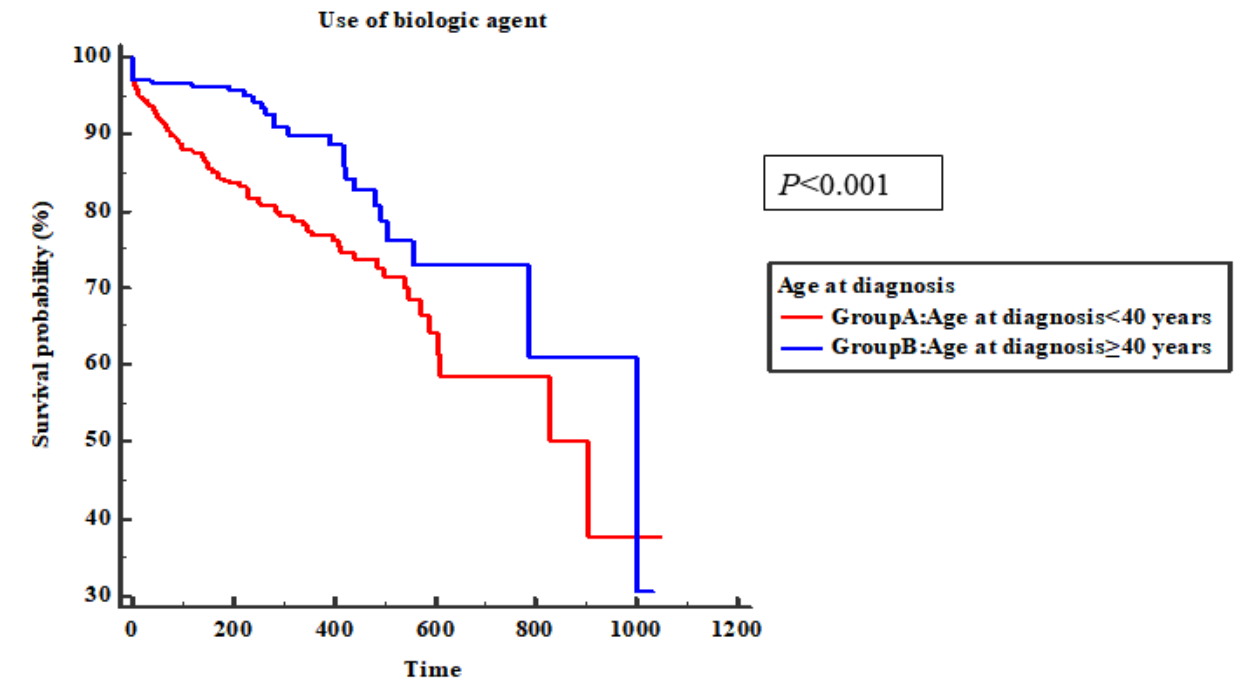

\begin{tabular}{l|lllllll|}
\hline Group A: & 978 & 306 & 105 & 24 & 7 & 2 & 0 \\
\begin{tabular}{|l} 
Group B: \\
378
\end{tabular} & 155 & 64 & 18 & 4 & 1 & 0
\end{tabular}

\section{Factors Related to Previous Biologic-Agent Therapy}

The Cox proportional hazards analysis showed that after adjustment for covariates, the odds ratio (OR) for the initiation of biologic-agent therapy in the EO UC group compared with the LO UC group was 2.3 (95\% CI 1.3-3.8, $P=.002$ ) (Table 4). The OR for initiation of biologic-agent therapy in the EO CD group compared with the LO CD group was 5.4 (95\% CI 1.9-14.9, $P=.001$ ) (Table 5). 
Table 4. Multivariate analysis for the detection of associative valuables with experience of biologic agent in ulcerative colitis.

\begin{tabular}{|c|c|c|}
\hline Characteristics & Odds ratio $(95 \% \mathrm{CI})$ & $P$ value \\
\hline \multicolumn{3}{|l|}{ Sex } \\
\hline Male & $1.4(0.8-2.3)$ & .19 \\
\hline \multicolumn{3}{|l|}{ Age at diagnosis } \\
\hline$<40$ years & $2.3(1.3-3.8)$ & .002 \\
\hline \multicolumn{3}{|l|}{ Phenotype of inflammatory bowel disease } \\
\hline Systemic steroid uses at the diagnosis & $2.1(1.2-3.6)$ & .01 \\
\hline \multicolumn{3}{|l|}{ Laboratory findings } \\
\hline Hemoglobin $<10 \mathrm{~g} / \mathrm{dL}$ & $1.1(0.5-2.2)$ & .79 \\
\hline C-reactive protein $\geq 3 \mathrm{~g} / \mathrm{dL}$ & $1.9(1.1-3.4)$ & .02 \\
\hline Albumin $<3.5 \mathrm{~g} / \mathrm{dL}$ & $2.2(1.2-3.9)$ & .01 \\
\hline
\end{tabular}

Table 5. Multivariate analysis for the detection of associative valuables with experience of biologic agent in Crohn's disease.

\begin{tabular}{lcc}
\hline Characteristics & Odds ratio $(95 \% \mathrm{CI})$ & $P$ value \\
\hline Sex $\quad$ & $0.9(0.5-1.7)$ & .81 \\
$\quad$ Male & & .001 \\
Age at diagnosis & $5.4(1.9-14.9)$ & \\
$\quad<40$ years & & .009 \\
Phenotype of inflammatory bowel disease & $2.2(1.2-4.1)$ & .31 \\
$\quad$ Systemic steroid uses at the diagnosis & & .05 \\
Laboratory findings & $1.4(0.7-2.9)$ \\
$\quad$ Hemoglobin $<10 \mathrm{~g} / \mathrm{dL}$ & $1.7(0.9-2.9)$ \\
$\quad$ C-reactive protein $\geq 3 \mathrm{~g} / \mathrm{dL}$ & $1.5(0.8-2.8)$ & .19 \\
$\quad$ Albumin $<3.5 \mathrm{~g} / \mathrm{dL}$ & $1.2(0.7-2.0)$ & .49 \\
$\quad$ High-density lipoprotein cholesterol $\leq 40 \mathrm{~g} / \mathrm{dL}$ & & \\
\hline
\end{tabular}

\section{Discussion}

\section{Principal Results}

In this study we found that patients with EO IBD had a worsened prognosis in terms of the first administration of biologic agents than patients with LO IBD. In the Cox proportional hazards analysis, the OR for the initiation of therapy with biologic agents was 2.3 (95\% CI 1.3-3.8, $P=.002)$ in the EO UC group compared with the LO UC group. For CD, the OR was 5.4 (95\% CI $1.9-14.9, P=.001)$ in the EO CD group compared with the LO CD group.

We also validated the utility of the K-CDM model for multicenter gastrointestinal studies in terms of its accuracy, efficacy, and transparency. To our knowledge, this is the first study to apply and validate the CDM for gastrointestinal research. We first transformed the EMRs to the K-CDM version 5.0 and subsequently assessed the association of the age at diagnosis with the prognosis of IBD using the K-CDM network data.

\section{Comparison With Prior Work}

The K-CDM uses the OHDSI database system, which aims to facilitate global, large-scale observational research that is reproducible, because it is based on CDMs and queries [18,36-39]. CDMs were developed to enable management of large amounts of data in the medical field. The use of standardized CDMs in research has several advantages, including speed and the use of standard analytical tools for different EMR database systems [18,38-44]. In this study, we used MS-SQL (Microsoft, Redman, WA) data-management software to analyze the EMR data from several tertiary medical centers.

There have been several attempts to use CDMs in the medical field [4,45-48]. Yue et al [49] used CDMs in studies on traumatic brain injury and overviewed the pertinent traumatic brain injury modules and CDMs. Amel et al [50] evaluated the clinical outcomes of mitochondrion-related diseases using a CDM specific to neurological diseases. Panaccio et al [51] used a CDM to analyze the hospitalization and mortality rates of patients with atrial fibrillation using a standardized methodology as well as coding algorithms across two types of data sources. However, no gastrointestinal study to date has used a CDM. In this study, we validated the utility of a CDM for gastrointestinal research.

Unlike other disease-specific CDMs [46,51], the K-CDM transforms almost all of the outpatient and inpatient data in each 
hospital. Therefore, the K-CDM data can be used for research related to a variety of medical specialties [16-18]. Moreover, the K-CDM is based on the OHDSI database framework, which enables its use in multicenter studies worldwide.

In this study, we found that age at diagnosis was associated with a poor prognosis of IBD (ie, use of biologic agents) $[10,11,15,52]$, and that EO UC and EO CD were associated with more frequent exacerbation events and earlier initiation of therapy with a biologic agent. Balde et al [53] reported that the use of biologic agents was more frequent in French patients with EO CD, which suggests a poor prognosis. Hwang et al [35] reported that among 1382 Korean patients with $C D$, the EO group had a worse prognosis, as reflected by a lower frequency of biologic agent use during the follow-up period.

In Korea, there have been emerging movements to share EMR data in the form of CDMs. To achieve this data-sharing process, more than 40 tertiary medical centers in Korea have made efforts to transform their EMR data in to CDM format using OHDSI open-source resources since 2018. Before the launching of the formal OHDSI platform-based study, we used Atlas or Achilles tools to build codes and extract data from the individual institutes and then analyzed the results in a meta-analysis to protect the distributed data system concepts; we intended to determine if gastroenterology researches using CDMs were more accurate and convenient than conventional study processes. We extracted the CDM-based data from the GMC and K-CDM network using MS-SQL and merged the data for further logrank tests and Cox proportional analyses. Even though this was not identical to typical OHDSI network studies, our study process had value by validating the CDM model in gastrointestinal research.

\section{Limitations}

Studies using the K-CDM have several limitations. First, many IBD-related factors, including disease activity at the time of diagnosis, initial UC Mayo score, and the CD activity index, were not included. Instead, we regarded use of systemic steroids or other immunosuppressive agents at the time of diagnosis as indicative of disease activity. The Korean IBD treatment guidelines state that systemic steroids or other immunosuppressive agents should be prescribed only to patients with moderate or severe diseases [33]. Moreover, in Korea, biologic-agent therapy is typically delayed until the second exacerbation event or until the patient is unresponsive to, or dependent on steroids or immunosuppressants for at least 3 months after the diagnosis of IBD. Therefore, in Korea, the use of biologic agents is indicative of a poor prognosis [33]. The UC Mayo score and CD activity index reflect the disease severity. Systemic steroid use at the time of diagnosis is indicative of moderate-to-severe and severe IBD activities. Thus, we used the systemic steroid use at the time of diagnosis as the operational definition of the UC Mayo score and the CD activity score. Gastroenterologists should focus on and make efforts to qualify the variables in the K-CDM network in gastrointestinal research. It is promising that the majority of the clinical contents used in gastrointestinal research could be equipped in the K-CDM tables, especially through the standardized clinical data domain, once researchers qualify the variables of the K-CDM. Second, this was a retrospective study and thus may have been influenced by selection or indication bias. Third, inclusion of only tertiary medical centers may have introduced selection bias.

\section{Conclusion}

In conclusion, patients with EO IBD have a worse prognosis than patients with LO IBD. Moreover, we successfully validated that the K-CDM network database enables physicians to conduct multicenter gastroenterology studies with more efficient and transparent study processes.

\section{Acknowledgments}

This research was supported by the Basic Science Research Program through the National Research Foundation of Korea (NRF) funded by the Ministry of Education (2017R1D1A1B03034546), and supported by a grant of the Korea Health Technology R\&D Project through the Korea Health Industry Development Institute (KHIDI), funded by the Ministry of Health \& Welfare, Republic of Korea (grant number: HI14C3201).

\section{Authors' Contributions}

The guarantor and corresponding author for this study is YJK. YIC, DKP, and YJK contributed to the study concept and design, acquisition analysis, interpretation of data, drafting of the manuscript, and obtainment of funding. RWP and HK contributed to the study analysis, interpretation of data, and critical revisions of the manuscript. J-WC, KOK, and Kwang An Kwon contributed to the study design and critical revisions of the manuscript. All authors read and approved the final manuscript.

\section{Conflicts of Interest}

None declared.

\section{References}

1. Kaplan GG. The global burden of IBD: from 2015 to 2025. Nat Rev Gastroenterol Hepatol 2015 Dec;12(12):720-727. [doi: 10.1038/nrgastro.2015.150] [Medline: 26323879] 
2. Lima Martins A, Volpato RA, Zago-Gomes MDP. The prevalence and phenotype in Brazilian patients with inflammatory bowel disease. BMC Gastroenterol 2018 Jun 18;18(1):87 [FREE Full text] [doi: 10.1186/s12876-018-0822-y] [Medline: 29914399]

3. Ng SC, Shi HY, Hamidi N, Underwood FE, Tang W, Benchimol EI, et al. Worldwide incidence and prevalence of inflammatory bowel disease in the 21st century: a systematic review of population-based studies. Lancet 2018 Dec 23;390(10114):2769-2778. [doi: 10.1016/S0140-6736(17)32448-0] [Medline: 29050646]

4. Kamm MA. Rapid changes in epidemiology of inflammatory bowel disease. Lancet 2018 Dec 23;390(10114):2741-2742. [doi: 10.1016/S0140-6736(17)32669-7] [Medline: 29050647]

5. Molodecky NA, Soon IS, Rabi DM, Ghali WA, Ferris M, Chernoff G, et al. Increasing incidence and prevalence of the inflammatory bowel diseases with time, based on systematic review. Gastroenterology 2012 Jan;142(1):46-54.e42; quiz e30. [doi: 10.1053/j.gastro.2011.10.001] [Medline: 22001864]

6. Ng SC, Bernstein CN, Vatn MH, Lakatos PL, Loftus EV, Tysk C, et al. Geographical variability and environmental risk factors in inflammatory bowel disease. Gut 2013 Apr;62(4):630-649. [doi: 10.1136/gutjnl-2012-303661] [Medline: 23335431]

7. Salgado VCL, Luiz RR, Boechat N, Schorr BC, Leão IS, Nunes T, et al. Crohn's disease environmental factors in the developing world: a case-control study in a statewide catchment area in Brazil. World J Gastroenterol 2017 Aug 14;23(30):5549-5556 [FREE Full text] [doi: 10.3748/wjg.v23.i30.5549] [Medline: 28852314]

8. Olén O, Askling J, Sachs MC, Frumento P, Neovius M, Smedby KE, et al. Childhood onset inflammatory bowel disease and risk of cancer: a Swedish nationwide cohort study 1964-2014. BMJ 2017 Sep 20;358:j3951 [FREE Full text] [doi: 10.1136/bmj.j3951] [Medline: 28931512]

9. Klement E, Lysy J, Hoshen M, Avitan M, Goldin E, Israeli E. Childhood hygiene is associated with the risk for inflammatory bowel disease: a population-based study. Am J Gastroenterol 2008 Jul;103(7):1775-1782. [doi:

10.1111/j.1572-0241.2008.01905.x] [Medline: 18557710 ]

10. Everhov ÅH, Halfvarson J, Myrelid P, Sachs MC, Nordenvall C, Söderling J, et al. Incidence and treatment of patients diagnosed with inflammatory bowel diseases at 60 years or older in Sweden. Gastroenterology 2018 Feb;154(3):518-528.e15. [doi: 10.1053/j.gastro.2017.10.034] [Medline: 29102619]

11. Ananthakrishnan AN, McGinley EL, Binion DG. Inflammatory bowel disease in the elderly is associated with worse outcomes: a national study of hospitalizations. Inflamm Bowel Dis 2009 Feb;15(2):182-189. [doi: 10.1002/ibd.20628] [Medline: 18668678 ]

12. Dulai PS, Boland BS, Singh S, Chaudrey K, Koliani-Pace JL, Kochhar G, et al. Development and validation of a scoring system to predict outcomes of vedolizumab treatment in patients with Crohn's disease. Gastroenterology 2018 Sep;155(3):687-695.e10 [FREE Full text] [doi: 10.1053/j.gastro.2018.05.039] [Medline: 29857091]

13. Khan NH, Almukhtar RM, Cole EB, Abbas AM. Early corticosteroids requirement after the diagnosis of ulcerative colitis diagnosis can predict a more severe long-term course of the disease - a nationwide study of 1035 patients. Aliment Pharmacol Ther 2014 Aug;40(4):374-381 [FREE Full text] [doi: 10.1111/apt.12834] [Medline: 24961751]

14. Baars JE, Kuipers EJ, van Haastert M, Nicolaï JJ, Poen AC, van der Woude CJ. Age at diagnosis of inflammatory bowel disease influences early development of colorectal cancer in inflammatory bowel disease patients: a nationwide, long-term survey. J Gastroenterol 2012 Dec;47(12):1308-1322 [FREE Full text] [doi: 10.1007/s00535-012-0603-2] [Medline: 22627504]

15. Israeli E, Ryan JD, Shafer L, Bernstein CN. Younger age at diagnosis is associated with panenteric, but not more aggressive, Crohn's disease. Clin Gastroenterol Hepatol 2014 Jan;12(1):72-79.e1. [doi: 10.1016/j.cgh.2013.06.027] [Medline: 23880115]

16. Cohen MZ, Thompson CB, Yates B, Zimmerman L, Pullen CH. Implementing common data elements across studies to advance research. Nurs Outlook 2015;63(2):181-188 [FREE Full text] [doi: 10.1016/j.outlook.2014.11.006] [Medline: 25771192]

17. Sheehan J, Hirschfeld S, Foster E, Ghitza U, Goetz K, Karpinski J, et al. Improving the value of clinical research through the use of Common Data Elements. Clin Trials 2016 Dec;13(6):671-676 [FREE Full text] [doi: 10.1177/1740774516653238] [Medline: 27311638]

18. Hripcsak G, Duke JD, Shah NH, Reich CG, Huser V, Schuemie MJ, et al. Observational Health Data Sciences and Informatics (OHDSI): opportunities for observational researchers. Stud Health Technol Inform 2015;216:574-578 [FREE Full text] [Medline: 26262116]

19. Hripcsak G, Ryan PB, Duke JD, Shah NH, Park RW, Huser V, et al. Characterizing treatment pathways at scale using the OHDSI network. Proc Natl Acad Sci U S A 2016 Dec 05;113(27):7329-7336 [FREE Full text] [doi: 10.1073/pnas.1510502113] [Medline: 27274072]

20. Zhou X, Murugesan S, Bhullar H, Liu Q, Cai B, Wentworth C, et al. An evaluation of the THIN database in the OMOP Common Data Model for active drug safety surveillance. Drug Saf 2013 Feb;36(2):119-134. [doi: 10.1007/s40264-012-0009-3] [Medline: 23329543]

21. Wu P, Cheng C, Kaddi CD, Venugopalan J, Hoffman R, Wang MD. -Omic and Electronic Health Record Big Data Analytics for Precision Medicine. IEEE Trans Biomed Eng 2017 Feb;64(2):263-273 [FREE Full text] [doi:

10.1109/TBME.2016.2573285] [Medline: 27740470] 
22. Belenkaya R, Gurley M, Dymshyts D, Araujo S, Williams A, Chen R, et al. Standardized observational cancer research using the OMOP CDM oncology module. Stud Health Technol Inform 2019 Aug 21;264:1831-1832. [doi: 10.3233/SHTI190670] [Medline: $\underline{31438365]}$

23. Jung Y, Hwangbo Y, Yoon SM, Koo HS, Shin HD, Shin JE, et al. Predictive factors for differentiating between Crohn's disease and intestinal tuberculosis in Koreans. Am J Gastroenterol 2016 Aug;111(8):1156-1164. [doi: 10.1038/ajg.2016.212] [Medline: 27296940]

24. Huang X, Liao W, Yu C, Tu Y, Pan X, Chen Y, et al. Differences in clinical features of Crohn's disease and intestinal tuberculosis. World J Gastroenterol 2015 Mar 28;21(12):3650-3656 [FREE Full text] [doi: 10.3748/wjg.v21.i12.3650] [Medline: 25834333]

25. Zumla A, George A, Sharma V, Herbert RHN, Baroness Masham of Ilton, Oxley A, et al. The WHO 2014 global tuberculosis report—further to go. Lancet Glob Health 2015 Jan;3(1):e10-e12 [FREE Full text] [doi: 10.1016/S2214-109X(14)70361-4] [Medline: 25539957]

26. Kim ES, Kim WH. Inflammatory bowel disease in Korea: epidemiological, genomic, clinical, and therapeutic characteristics. Gut Liver 2010 Mar;4(1):1-14 [FREE Full text] [doi: 10.5009/gnl.2010.4.1.1] [Medline: 20479907]

27. Lee J, Im JP, Han K, Kim J, Lee HJ, Chun J, et al. Changes in direct healthcare costs before and after the diagnosis of inflammatory bowel disease: a nationwide population-based study. Gut Liver 2020 Jan 15;14(1):89-99 [FREE Full text] [doi: 10.5009/gnl19023] [Medline: 31158951]

28. Baek S, Lee KY, Song KH, Yu CS. Current status and trends in inflammatory bowel disease surgery in Korea: analysis of data in a nationwide registry. Ann Coloproctol 2018 Dec;34(6):299-305 [FREE Full text] [doi: 10.3393/ac.2018.07.21] [Medline: $\underline{30630303}$ ]

29. Lamb CA, Kennedy NA, Raine T, Hendy PA, Smith PJ, Limdi JK, et al. British Society of Gastroenterology consensus guidelines on the management of inflammatory bowel disease in adults. Gut 2019 Dec;68(Suppl 3):s1-s106 [FREE Full text] [doi: 10.1136/gutjnl-2019-318484] [Medline: 31562236]

30. Rubin DT, Ananthakrishnan AN, Siegel CA, Sauer BG, Long MD. ACG clinical guideline: ulcerative colitis in adults. Am J Gastroenterol 2019 Mar;114(3):384-413. [doi: 10.14309/ajg.0000000000000152] [Medline: 30840605]

31. Lichtenstein GR, Loftus EV, Isaacs KL, Regueiro MD, Gerson LB, Sands BE. ACG clinical guideline: management of Crohn's disease in adults. Am J Gastroenterol 2018 Apr;113(4):481-517. [doi: 10.1038/ajg.2018.27] [Medline: 29610508]

32. Park JJ, Yang S, Ye BD, Kim JW, Park DI, Yoon H, et al. Second Korean guidelines for the management of Crohn's disease. Intest Res 2017 Jan;15(1):38-67 [FREE Full text] [doi: 10.5217/ir.2017.15.1.38] [Medline: 28239314]

33. Lee JW, Im JP, Cheon JH, Kim YS, Kim JS, Han DS. Inflammatory bowel disease cohort studies in Korea: present and future. Intest Res 2015 Jul;13(3):213-218 [FREE Full text] [doi: 10.5217/ir.2015.13.3.213] [Medline: 26130995]

34. Choi CH, Moon W, Kim YS, Kim ES, Lee B, Jung Y, et al. Second Korean guidelines for the management of ulcerative colitis. Intest Res 2017 Jan;15(1):7-37 [FREE Full text] [doi: 10.5217/ir.2017.15.1.7] [Medline: 28239313]

35. Hong SJ, Cho SM, Choe B, Jang HJ, Choi KH, Kang B, et al. Characteristics and incidence trends for pediatric inflammatory bowel disease in Daegu-Kyungpook province in Korea: a multi-center study. J Korean Med Sci 2018 Apr 30;33(18):e132 [FREE Full text] [doi: 10.3346/jkms.2018.33.e132] [Medline: 29713253]

36. Tobore I, Li J, Yuhang L, Al-Handarish Y, Kandwal A, Nie Z, et al. Deep learning intervention for health care challenges: some biomedical domain considerations. JMIR Mhealth Uhealth 2019 Aug 02;7(8):e11966 [FREE Full text] [doi: 10.2196/11966] [Medline: 31376272$]$

37. Fiske A, Prainsack B, Buyx A. Data work: meaning-making in the era of data-rich medicine. J Med Internet Res 2019 Jul 09;21(7):e11672 [FREE Full text] [doi: 10.2196/11672] [Medline: 31290397]

38. Zheng X, Sun S, Mukkamala RR, Vatrapu R, Ordieres-Meré J. Accelerating health data sharing: a solution based on the Internet of Things and distributed ledger technologies. J Med Internet Res 2019 Jun 06;21(6):e13583 [FREE Full text] [doi: 10.2196/13583] [Medline: $\underline{31172963]}$

39. Mavragani A, Ochoa G. Google trends in infodemiology and infoveillance: methodology framework. JMIR Public Health Surveill 2019 May 29;5(2):e13439 [FREE Full text] [doi: 10.2196/13439] [Medline: 31144671$]$

40. Carbonnel F, Ninot G. Identifying frameworks for validation and monitoring of consensual behavioral intervention technologies: narrative review. J Med Internet Res 2019 Oct 16;21(10):e13606 [FREE Full text] [doi: 10.2196/13606] [Medline: 31621638 ]

41. Katapally TR. The SMART framework: integration of citizen science, community-based participatory research, and systems science for population health science in the digital age. JMIR Mhealth Uhealth 2019 Aug 30;7(8):e14056 [FREE Full text] [doi: 10.2196/14056] [Medline: 31471963]

42. Kim HH, Kim B, Joo S, Shin S, Cha HS, Park YR. Why do data users say health care data are difficult to use? a cross-sectional survey study. J Med Internet Res 2019 Aug 06;21(8):e14126 [FREE Full text] [doi: 10.2196/14126] [Medline: 31389335$]$

43. McPadden J, Durant TJ, Bunch DR, Coppi A, Price N, Rodgerson K, et al. Health care and precision medicine research: analysis of a scalable data science platform. J Med Internet Res 2019 Apr 09;21(4):e13043 [FREE Full text] [doi: 10.2196/13043] [Medline: $\underline{30964441]}$ 
44. Mavragani A, Ochoa G, Tsagarakis KP. Assessing the methods, tools, and statistical approaches in Google trends research: systematic review. J Med Internet Res 2018 Nov 06;20(11):e270 [FREE Full text] [doi: 10.2196/jmir.9366] [Medline: $\underline{30401664]}$

45. Jiang G, Solbrig HR, Prud'hommeaux E, Tao C, Weng C, Chute CG. Quality assurance of cancer study Common Data Elements using a post-coordination approach. AMIA Annu Symp Proc 2015;2015:659-668 [FREE Full text] [Medline: 26958201]

46. Smith DH, Hicks RR, Johnson VE, Bergstrom DA, Cummings DM, Noble LJ, et al. Pre-clinical traumatic brain injury Common Data Elements: toward a common language across laboratories. J Neurotrauma 2015 Nov 15;32(22):1725-1735 [FREE Full text] [doi: 10.1089/neu.2014.3861] [Medline: 26058402]

47. Bell MJ, Kochanek PM. Pediatric traumatic brain injury in 2012: the year with new guidelines and common data elements. Crit Care Clin 2013 Apr;29(2):223-238 [FREE Full text] [doi: 10.1016/j.ccc.2012.11.004] [Medline: 23537673]

48. Kim M, Shin S, Kang M, Yi B, Chang DK. Developing a standardization algorithm for categorical laboratory tests for clinical big data research: retrospective study. JMIR Med Inform 2019 Aug 29;7(3):e14083 [FREE Full text] [doi: 10.2196/14083] [Medline: 31469075$]$

49. Yue JK, Vassar MJ, Lingsma HF, Cooper SR, Okonkwo DO, Valadka AB, TRACK-TBI Investigators. Transforming research and clinical knowledge in traumatic brain injury pilot: multicenter implementation of the common data elements for traumatic brain injury. J Neurotrauma 2013 Nov 15;30(22):1831-1844 [FREE Full text] [doi: 10.1089/neu.2013.2970] [Medline: 23815563]

50. Amre DK, Lambrette P, Law L, Krupoves A, Chotard V, Costea F, et al. Investigating the hygiene hypothesis as a risk factor in pediatric onset Crohn's disease: a case-control study. Am J Gastroenterol 2006 May;101(5):1005-1011. [doi: 10.1111/j.1572-0241.2006.00526.x] [Medline: 16573775]

51. Panaccio MP, Cummins G, Wentworth C, Lanes S, Reynolds SL, Reynolds MW, et al. A common data model to assess cardiovascular hospitalization and mortality in atrial fibrillation patients using administrative claims and medical records. Clin Epidemiol 2015;7:77-90 [FREE Full text] [doi: 10.2147/CLEP.S64936] [Medline: 25624771]

52. Malaty HM, Sansgiry S, Artinyan A, Hou JK. Time trends, clinical characteristics, and risk factors of chronic anal fissure among a national cohort of patients with inflammatory bowel disease. Dig Dis Sci 2016 Mar;61(3):861-864. [doi: 10.1007/s10620-015-3930-3] [Medline: 26514675]

53. Gower-Rousseau C, Dauchet L, Vernier-Massouille G, Tilloy E, Brazier F, Merle V, et al. The natural history of pediatric ulcerative colitis: a population-based cohort study. Am J Gastroenterol 2009 Aug;104(8):2080-2088. [doi:

10.1038/ajg.2009.177] [Medline: 19436273]

\author{
Abbreviations \\ CD: Crohn's disease \\ CDM: common data model \\ EMR: electronic medical record \\ EO: early-onset \\ GMC: Gill Medical Center \\ IBD: inflammatory bowel disease \\ K: Korean \\ LO: late-onset \\ OHDSI: Observational Health Data Sciences and Informatics \\ OR: odds ratio \\ UC: ulcerative colitis
}

Edited by G Eysenbach; submitted 26.06.19; peer-reviewed by S Esworthy, V Huser; comments to author $13.08 .19 ;$ revised version
received 23.10.19; accepted 27.01.20; published 15.04 .20
Please cite as:
Choi YI, Kim YJ, Chung JW, Kim KO, Kim H, Park RW, Park DK
Effect of Age on the Initiation of Biologic Agent Therapy in Patients With Inflammatory Bowel Disease: Korean Common Data Model
Cohort Study
JMIR Med Inform 2020;8(4):e15124
URL: $\underline{\text { https://medinform.jmir.org/2020/4/e15124 }}$
doi: $\underline{10.2196 / 15124}$
PMID: $\underline{32293578}$


(C)Youn I Choi, Yoon Jae Kim, Jun-Won Chung, Kyoung Oh Kim, Hakki Kim, Rae Woong Park, Dong Kyun Park. Originally published in JMIR Medical Informatics (http://medinform.jmir.org), 15.04.2020. This is an open-access article distributed under the terms of the Creative Commons Attribution License (https://creativecommons.org/licenses/by/4.0/), which permits unrestricted use, distribution, and reproduction in any medium, provided the original work, first published in JMIR Medical Informatics, is properly cited. The complete bibliographic information, a link to the original publication on http://medinform.jmir.org/, as well as this copyright and license information must be included. 